\title{
Marinobacter bryozoorum sp. nov. and Marinobacter sediminum sp. nov., novel bacteria from the marine environment
}

Correspondence

Erko Stackebrandt

Erko@dsmz.de

\author{
Lyudmila A. Romanenko, ${ }^{1}$ Peter Schumann, ${ }^{2}$ Manfred Rohde, ${ }^{3}$ \\ Natalia V. Zhukova, ${ }^{4}$ Valery V. Mikhailov ${ }^{1}$ and Erko Stackebrandt ${ }^{2}$
${ }^{1}$ Pacific Institute of Bioorganic Chemistry, Far-Eastern Branch, Russian Academy of Sciences, 690022 Vladivostok, Prospekt 100 Let Vladivostoku, 159, Russia
${ }^{2} \mathrm{DSMZ}$ - Deutsche Sammlung von Mikroorganismen und Zellkulturen GmbH, Mascheroder Weg 1b, D-38124 Braunschweig, Germany
${ }^{3} \mathrm{GBF}$ - Gesellschaft für Biotechnologische Forschung GmbH, D-38124 Braunschweig, Germany
${ }^{4}$ Institute of Marine Biology, Far-Eastern Branch, Russian Academy of Sciences, 690041 Vladivostok, Russia

The genus Marinobacter was described by Gauthier et al. (1992) and currently comprises eight species, four of which were described in 2003 [Marinobacter excellens (Gorshkova et al., 2003), Marinobacter litoralis (Yoon et al., 2003), Marinobacter lipolyticus (Martín et al., 2003) and Marinobacter lutaoensis (Shieh et al., 2003)] and two in 2004 [Marinobacter daepoensis and Marinobacter flavimaris (Yoon et al., 2004)]. The type species is Marinobacter hydrocarbonoclasticus (Gauthier et al., 1992). In the course of studying the diversity of halophilic bacteria associated with the marine environment, strains $\mathrm{KMM} 3657^{\mathrm{T}}\left(=\mathrm{R} 65^{\mathrm{T}}\right)$ and KMM $3840^{\mathrm{T}}\left(=50-11^{\mathrm{T}}\right)$ were isolated from a sediment sample obtained from Peter the Great Bay, Sea of Japan, Russia, and from a Bryozoan specimen collected in the Bering Sea, August 1991, respectively. Aliquots of the diluted sediment sample and homogenized internal tissues of the Bryozoan specimen were spread on agar plates of sea water medium (SWM), containing $\left(1^{-1}\right): 5.0 \mathrm{~g}$ peptone, $2.5 \mathrm{~g}$ yeast extract, $1.0 \mathrm{~g}$ glucose, $0.2 \mathrm{~g} \mathrm{~K}_{2} \mathrm{HPO}_{4}, 0.05 \mathrm{~g}$

The GenBank/EMBL/DDBJ accession numbers for the 16S rRNA gene sequences of KMM $3657^{\top}$ and $\mathrm{KMM} 3840^{\top}$ are AJ609270 and AJ609271, respectively.
$\mathrm{MgSO}_{4}, 500 \mathrm{ml}$ sea water, $500 \mathrm{ml}$ distilled water and $15 \cdot 0 \mathrm{~g}$ agar. Samples were incubated for 7 days at $28^{\circ} \mathrm{C}$. Each colony was streaked and cultivated on nutrient medium containing sodium ions or natural sea water. Strains KMM $3657^{\mathrm{T}}$ and $\mathrm{KMM} 3840^{\mathrm{T}}$, deposited in the Collection of Marine Micro-organisms (KMM), Pacific Institute of Bioorganic Chemistry, Vladivostok, Russia, were stored at $-80{ }^{\circ} \mathrm{C}$ in liquid nutrient medium supplemented with $20 \%$ $(\mathrm{v} / \mathrm{v})$ glycerol. Strains were routinely grown on marine 2216 agar (MA; Difco), marine broth (MB; Difco) and SWM. Standard tests, Gram-reaction evaluation and determination of oxidase, catalase, amylase, caseinase, chitinase and gelatinase activities were carried out as described by Smibert \& Krieg (1994). Growth at different temperatures $\left(4-50^{\circ} \mathrm{C}\right)$ and $\mathrm{pH}$ values $(\mathrm{pH} 5 \cdot 0-10 \cdot 0)$ was examined on $\mathrm{MA}$ and MB media, respectively. Requirement and tolerance of various $\mathrm{NaCl}$ concentrations were determined using SWM prepared on the artificial sea water base supplemented with the appropriate $\mathrm{NaCl}$ concentrations $(0,0 \cdot 5,1$, $3,5,8,10,15,18,18 \cdot 5,20,25$ and $30 \%, w / v)$. Leifson's medium was used to test acid production from carbohydrates with $1 \%(\mathrm{w} / \mathrm{v})$ of each compound (Leifson, 1963). In addition, biochemical tests were performed using the API 
20NE and API ZYM test kits (bioMérieux) according to the manufacturer's instructions, except that the cultures were suspended in $3 \%(\mathrm{w} / \mathrm{v}) \mathrm{NaCl}$ solution. The isolates were also characterized using the Biolog GN MicroPlate panel. Strains were grown on MA medium at $28^{\circ} \mathrm{C}$ for $24 \mathrm{~h}$ and the microtitre plates were inoculated with cells suspended in $3 \%(\mathrm{w} / \mathrm{v}) \mathrm{NaCl}$ solution. Results were read automatically with a spectrophotometer after 24, 48 and $96 \mathrm{~h}$ and for up to 7 days incubation at $28^{\circ} \mathrm{C}$. The DNA G $+\mathrm{C}$ content was determined as described by Marmur \& Doty (1962) with the modification of Owen et al. (1969). Fatty acid methyl esters were analysed using the standard procedure of the Microbial Identification system (Microbial ID) and compared to the fatty acid database. For fatty acid methyl ester analysis, bacteria were grown on MA for 3 days at $28^{\circ} \mathrm{C}$. Genomic DNA extraction, PCR-mediated amplification of the 16S rRNA gene and sequencing of PCR products were carried out as described by Rainey et al. (1996). Purified PCR products were sequenced directly using a Taq DyeDeoxy Terminator Cycle Sequencing kit (Applied Biosystems) according to the manufacturer's instructions. The Applied Biosystems 310 DNA Genetic Analyzer was used for electrophoresis of the sequence reaction products. The 16S rRNA gene sequences were aligned manually with nucleotide sequences obtained from GenBank and EMBL. The method of Jukes \& Cantor (1969) was applied to calculate evolutionary distances. Phylogenetic dendrograms were reconstructed according to the method of De Soete (1983) and the neighbour-joining method contained in the PHYLIP package (Felsenstein, 1993). The accession numbers of the reference strains used in the phylogenetic analysis are shown in Fig. 2. Automated ribotyping of the isolates was accomplished using the RiboPrinter (Qualicon) system (Allerberger \& Fritschel, 1999) and EcoRI as the restriction enzyme for cutting the genomic DNA. The patterns were compared to those included in the DSMZ RiboPrint database.

The marine isolates KMM $3840^{\mathrm{T}}$ and $\mathrm{KMM} 3657^{\mathrm{T}}$ were Gram-negative, aerobic, oxidase- and catalase-positive, non-pigmented, halophilic bacteria. The strains studied were motile, rod-shaped organisms that differed slightly in their cell morphology. Cells of KMM $3840^{\mathrm{T}}$ were ovoid, $1 \cdot 0-1 \cdot 3 \mu \mathrm{m}$ long and $0 \cdot 4-0 \cdot 5 \mu \mathrm{m}$ in diameter (Fig. 1a), whereas those of $\mathrm{KMM} 3657^{\mathrm{T}}$ were long rods, $1 \cdot 8-2 \cdot 5 \mu \mathrm{m}$ long and $0 \cdot 3-0 \cdot 4 \mu \mathrm{m}$ in diameter (Fig. 1b). Isolates KMM $3840^{\mathrm{T}}$ and $\mathrm{KMM} 3657^{\mathrm{T}}$ required sodium ions for growth and grew in $1.0-18.0 \%(\mathrm{w} / \mathrm{v}) \mathrm{NaCl}$ at $7-42^{\circ} \mathrm{C}$ and $0 \cdot 5-18 \cdot 0 \%(\mathrm{w} / \mathrm{v}) \mathrm{NaCl}$ at $4-42{ }^{\circ} \mathrm{C}$, respectively.

According to 16S rRNA gene sequence analysis, strains KMM $3840^{\mathrm{T}}$ and KMM $3657^{\mathrm{T}}$ were closely related to each other phylogenetically ( $96 \cdot 6 \%$ sequence similarity) and showed moderate to close gene sequence relatedness to some Marinobacter type strains, i.e. M. lipolyticus $\mathrm{SM} 19^{\mathrm{T}}$, M. hydrocarbonoclasticus DSM $8798^{\mathrm{T}}$ and Marinobacter aquaeolei $\mathrm{VT}^{\mathrm{T}}$ (sequence similarity values of $96 \cdot 6,96 \cdot 1$ and $96 \cdot 1 \%$ to $\mathrm{KMM} 3840^{\mathrm{T}}$ and $98 \cdot 0,96 \cdot 4$ and $96 \cdot 6 \%$ to
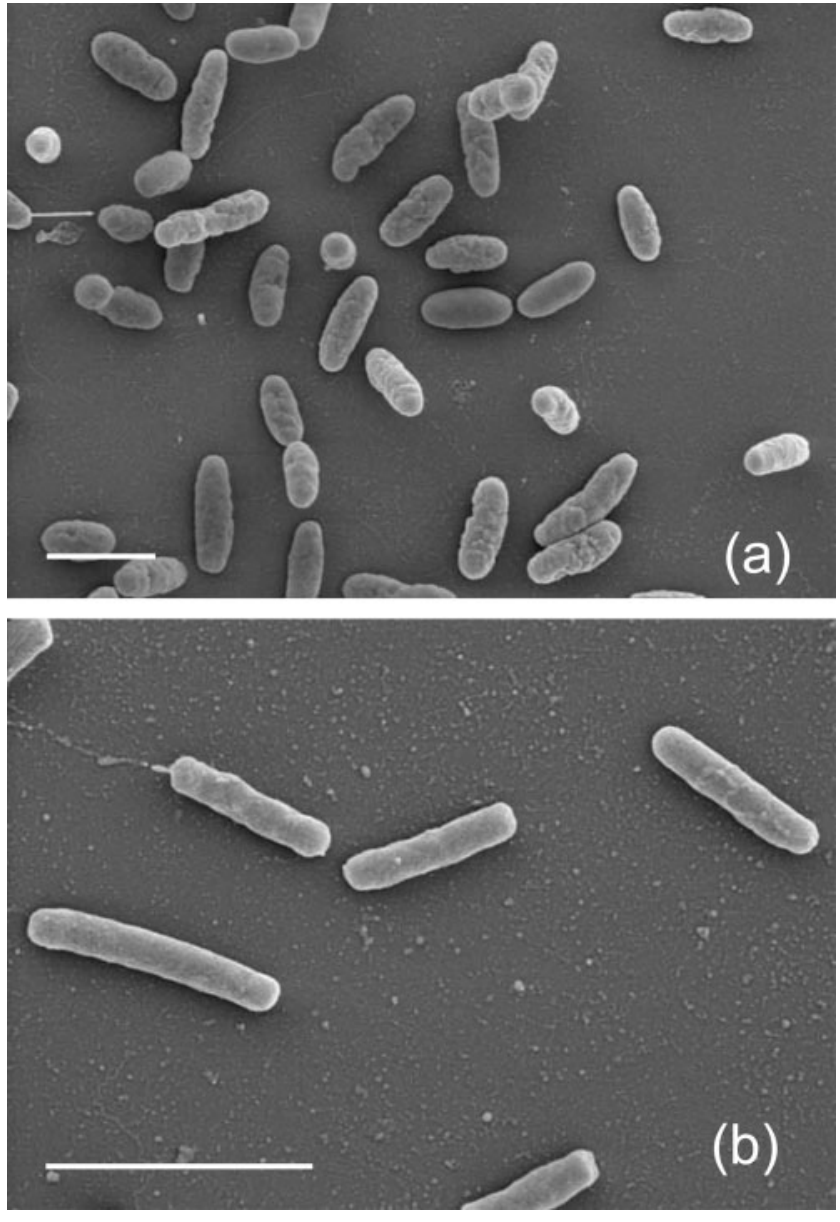

Fig. 1. Scanning electron micrographs of strains $\mathrm{KMM} 3840^{\top}$ (a) and $\mathrm{KMM} 3657^{\top}$ (b). Bars, $2 \mu \mathrm{m}$.

KMM $3657^{\mathrm{T}}$, respectively). The sequence divergence values of $>2 \%$ obtained for the novel isolates and previously described Marinobacter type strains exceeded the value accepted as criteria for the delineation of different species (Stackebrandt \& Goebel, 1994). The phylogenetic position of the two isolates was identical using two different treeing algorithms. Fig. 2 displays the dendrogram based on neighbour-joining analysis (Felsenstein, 1993). Ribotyping analysis (Fig. 3), which served as a basis for molecular identification, revealed individual patterns for the two novel isolates, thus confirming the differences between strain KMM $3657^{\mathrm{T}}$ and M. lipolyticus DSM $15157^{\mathrm{T}}$.

The physiological and genomic characteristics of strains KMM $3840^{\mathrm{T}}$ and $\mathrm{KMM} 3657^{\mathrm{T}}$ were compared with those of other species of Marinobacter (Table 1). Some biochemical characteristics and carbon sources for growth were similar between the novel isolates and other Marinobacter species, but many differences were found that allowed them to be distinguished from each other (Table 1). Both strains examined could be distinguished from related Marinobacter species in their maximal growth temperature, salinity 


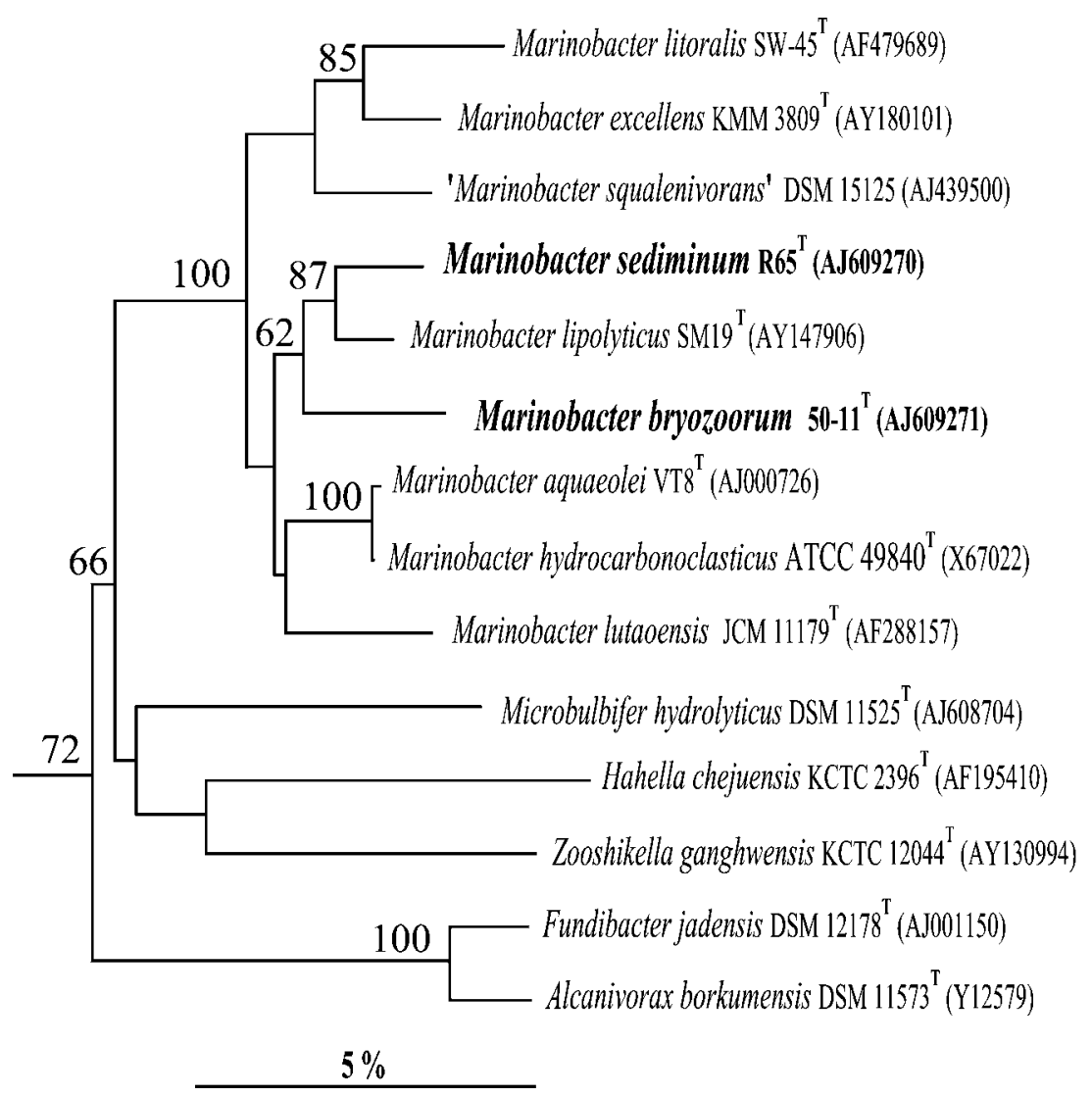

Fig. 2. Dendrogram, constructed using $16 \mathrm{~S}$ rRNA gene sequences (Felsenstein, 1993), showing the phylogenetic positions of the novel members of the genus Marinobacter. Numbers indicate the percentage of bootstrap samplings, derived from 500 resamplings. Bar, $5 \%$ sequence divergence. More distantly related members of the $\gamma$-Proteobacteria served as a root. Numbers in parentheses are GenBank/EMBL/DDBJ accession numbers for the 16S rRNA gene sequences. range for growth, narrow spectrum of organic substrates that could be utilized as sole carbon sources, weak or negative enzymic reactions and DNA $\mathrm{G}+\mathrm{C}$ content (Table 1). Other reactions obtained by API 20NE, API ZYM and Biolog are indicated in the species description.

The fatty acid compositions of the isolates are shown in Table 2. The fatty acids $\mathrm{C}_{12: 0} 3-\mathrm{OH}, \mathrm{C}_{16: 0}, \mathrm{C}_{16: 1} \omega 9 c$ and $\mathrm{C}_{18: 1} \omega 9 c$ have been reported to be predominant in the cellular fatty acid compositions of known Marinobacter species (Spröer et al., 1998; Nguyen et al., 1999; Martín et al.,

M. sediminum DSM $15400^{\mathrm{T}}$

Fig. 3. Diversity of normalized EcoRl ribotype patterns found within the novel members of the genus Marinobacter and their phylogenetic neighbours.
2003; Yoon et al., 2003). Strain KMM $3657^{\mathrm{T}}$ possessed significant amounts of $\mathrm{C}_{16: 1} \omega 7 c(15 \cdot 87 \%)$, whereas strain KMM $3840^{\mathrm{T}}$ differed from other Marinobacter strains by having a high proportion of $\mathrm{C}_{18: 1} \omega 9 c$ and a low level of $\mathrm{C}_{16: 1} \omega 9 c$ (Table 2). The DNA G $+\mathrm{C}$ content of KMM $3657^{\mathrm{T}}$ was $56.5 \mathrm{~mol} \%$, whereas that of strain $\mathrm{KMM} 3840^{\mathrm{T}}$ was found to be slightly higher $(59.6 \mathrm{~mol} \%)$ than those of the other Marinobacter strains, which range between 55 and $57 \mathrm{~mol} \%$.

On the basis of the physiological and molecular properties, it is proposed that isolates KMM $3840^{\mathrm{T}}$ and KMM $3657^{\mathrm{T}}$ represent two novel species in the genus Marinobacter, Marinobacter bryozoorum sp. nov. and Marinobacter sediminum sp. nov., respectively.

\section{Description of Marinobacter bryozoorum sp. nov.}

Marinobacter bryozoorum [bry.o.zo.o'rum. N.L. gen. pl. n. bryozoorum of Bryozoan (bryozoans), marine invertebrate specimen, source of isolation].

Gram-negative, aerobic, heterotrophic, oxidase- and catalase-positive, motile and rod-shaped $(1 \cdot 0-1 \cdot 3 \mu \mathrm{m}$ long and $0 \cdot 4-0 \cdot 5 \mu \mathrm{m}$ in diameter). Requires sodium ions for growth. Grows in $1 \cdot 0-18 \cdot 0 \%(\mathrm{w} / \mathrm{v}) \mathrm{NaCl}$ at $7-42^{\circ} \mathrm{C}$. No growth observed in $>18.5 \% \mathrm{NaCl}$ or at $>43^{\circ} \mathrm{C}$. Colonies on MA are non-pigmented, whitish, translucent and smooth, 
Table 1. Phenotypic characteristics of $\mathrm{KMM} 3840^{\top}, \mathrm{KMM} 3657^{\top}$ and phylogenetically related Marinobacter species

Species/strains: 1, KMM 3840T ; 2, KMM 3657 ; 3, M. hydrocarbonoclasticus; 4, M. lipolyticus; 5, M. aquaeolei; 6, M. litoralis. Data were obtained from this study and the following references: Gauthier et al. (1992), Nguyen et al. (1999), Yoon et al. (2003) and Martín et al. (2003). All strains are positive for motility, catalase, oxidase, alkaline phosphatase, naphthol-AS-BI-phosphohydrolase and $N$-acetyl- $\beta$ glucosaminidase (strain $\mathrm{SM} 19^{\mathrm{T}}$ was not tested). All strains are negative for arginine dihydrolase, lipase C14, cystine arylamidase, trypsin, $\alpha$-chymotrypsin, $\alpha$-galactosidase, $\beta$-galactosidase, $\beta$-glucuronidase, $\alpha$-glucosidase, $\beta$-glucosidase, $\alpha$-mannosidase and $\alpha$-fucosidase (strain $\mathrm{SM} 19^{\mathrm{T}}$ was not tested), and utilization of D-fructose, D-mannitol, D-gluconate and L-arginine (strain SM19 ${ }^{\mathrm{T}}$ was not tested). + , Positive; -, negative; W, weak reaction; $\mathrm{V}$, variable; ND, not determined.

\begin{tabular}{|c|c|c|c|c|c|c|}
\hline Feature & 1 & 2 & 3 & 4 & 5 & 6 \\
\hline \multirow[t]{2}{*}{ Cell size $(\mu \mathrm{m})$} & $0 \cdot 4-0 \cdot 5 \times$ & $0 \cdot 3-0 \cdot 4 \times$ & $0 \cdot 3-0 \cdot 6 \times$ & $0 \cdot 3-0 \cdot 5 \times$ & $0 \cdot 4-0 \cdot 5 \times$ & $0 \cdot 5-0 \cdot 8 \times$ \\
\hline & $1 \cdot 0-1 \cdot 3$ & $1 \cdot 8-2 \cdot 5$ & $2 \cdot 0-3 \cdot 0$ & $2 \cdot 5-3 \cdot 5$ & $1 \cdot 4-1 \cdot 6$ & $1 \cdot 5-3 \cdot 0$ \\
\hline Nitrite reduction to $\mathrm{N}_{2}$ & - & - & + & - & - & - \\
\hline \multicolumn{7}{|l|}{ Growth in/at: } \\
\hline $0 \% \mathrm{NaCl}$ & - & - & - & - & + & - \\
\hline $20 \% \mathrm{NaCl}$ & - & - & + & - & + & - \\
\hline $4{ }^{\circ} \mathrm{C}$ & - & + & - & - & - & + \\
\hline Maximum growth temperature $\left({ }^{\circ} \mathrm{C}\right)$ & 42 & 42 & 45 & 37 & 50 & 46 \\
\hline \multicolumn{7}{|l|}{ Hydrolysis of: } \\
\hline Tween 80 & - & $\mathrm{W}$ & + & + & + & + \\
\hline Gelatin & - & - & $\mathrm{V}$ & - & + & - \\
\hline Urease & - & - & - & ND & + & + \\
\hline \multicolumn{7}{|l|}{ Utilization of: } \\
\hline Adipate & + & - & + & $\mathrm{ND}$ & - & $\mathrm{ND}$ \\
\hline Citrate & - & - & + & - & + & $\mathrm{ND}$ \\
\hline D-Glucose & - & + & - & + & - & - \\
\hline D-Mannose & + & + & + & - & + & + \\
\hline Cellobiose & + & + & + & - & + & + \\
\hline Sucrose & + & + & + & - & + & + \\
\hline Glycerol & + & + & + & - & + & + \\
\hline L-Serine & + & + & + & - & + & + \\
\hline Malate & - & - & + & $\mathrm{ND}$ & ND & $\mathrm{ND}$ \\
\hline Acetate & - & - & + & - & + & ND \\
\hline Butyrate & - & - & + & ND & + & ND \\
\hline DL-Lactate & - & - & + & - & + & ND \\
\hline L-Glutamate & - & - & + & - & + & + \\
\hline L-Proline & - & - & + & - & + & ND \\
\hline L-Leucine & - & - & - & - & + & ND \\
\hline L-Alanine & - & - & - & - & + & ND \\
\hline \multicolumn{7}{|l|}{ API ZYM tests: } \\
\hline Esterase C4 & - & - & + & ND & + & + \\
\hline Esterase lipase C8 & $\mathrm{W}$ & $\mathrm{W}$ & + & $\mathrm{ND}$ & + & + \\
\hline Leucine arylamidase & + & $\mathrm{W}$ & + & ND & + & + \\
\hline Valine arylamidase & $\mathrm{W}$ & - & $\mathrm{W}$ & $\mathrm{ND}$ & + & - \\
\hline Acid phosphatase & $\mathrm{W}$ & - & + & ND & + & + \\
\hline DNA G $+\mathrm{C}$ content $(\mathrm{mol} \%)$ & $59 \cdot 6$ & $56 \cdot 5$ & $57 \cdot 5$ & $57 \cdot 0$ & $55 \cdot 7$ & 55 \\
\hline
\end{tabular}

2-3 $\mathrm{mm}$ in diameter. In addition to the phenotypic characteristics indicated in Table 1, the type strain does not produce caseinase, amylase or chitinase. Does not produce acid from glucose, sucrose, lactose, maltose, galactose, arabinose, rhamnose, $N$-acetylglucosamine, glycerol or mannitol (determined by Leifson's method). According to API 20NE, positive for nitrate reduction and adipate utilization, and negative for indole production, arginine dihydrolase, urease production, aesculin, gelatin, $\beta$-galactosidase and utilization of D-glucose, D-mannitol, maltose, L-arabinose, D-mannose, $N$-acetylglucosamine, D-gluconate, caprate, L-malate, citrate and phenylacetate. Biolog GN MicroPlate tests were positive for utilization of Tween 40 and methyl pyruvate and negative for the other organic compounds included in the Biolog panel. The whole-cell fatty acid composition is given in Table 2. 
Table 2. Fatty acid composition (\%) of $\mathrm{KMM} 3840^{\top}$, $\mathrm{KMM}$ $3657^{\top}$ and some Marinobacter species

Strains: 1, KMM $3840^{\mathrm{T}}$; 2, KMM $3657^{\mathrm{T}}$; 3, M. hydrocarbonoclasti-

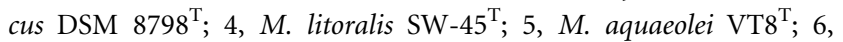
M. lipolyticus $\mathrm{SM} 19^{\mathrm{T}}$. Data for Marinobacter species from Nguyen et al. (1999), Yoon et al. (2003) and Martín et al. (2003). ND, Not determined.

\begin{tabular}{|lcccccc|}
\hline Fatty acid & $\mathbf{1}$ & $\mathbf{2}$ & $\mathbf{3}$ & $\mathbf{4}$ & $\mathbf{5}$ & $\mathbf{6}$ \\
\hline $\mathrm{C}_{12: 0}$ & $5 \cdot 58$ & $4 \cdot 15$ & $4 \cdot 66$ & $5 \cdot 5$ & $7 \cdot 89$ & $8 \cdot 3$ \\
$\mathrm{C}_{12: 0} 3-\mathrm{OH}$ & $10 \cdot 68$ & $8 \cdot 04$ & $7 \cdot 74$ & $9 \cdot 6$ & $9 \cdot 94$ & $11 \cdot 3$ \\
$\mathrm{C}_{14: 0}$ & $0 \cdot 81$ & $0 \cdot 92$ & $2 \cdot 24$ & $3 \cdot 0$ & $2 \cdot 60$ & 0 \\
$\mathrm{C}_{15: 0}$ & 0 & 0 & $1 \cdot 36$ & $0 \cdot 7$ & $2 \cdot 24$ & $1 \cdot 0$ \\
$\mathrm{C}_{16: 0}$ & $17 \cdot 45$ & $21 \cdot 78$ & $23 \cdot 59$ & $25 \cdot 0$ & $22 \cdot 62$ & $28 \cdot 5$ \\
$\mathrm{C}_{16: 1} \omega 9 c$ & $3 \cdot 67$ & $13 \cdot 28$ & $7 \cdot 40$ & $10 \cdot 6$ & $11 \cdot 62$ & $10 \cdot 5$ \\
$\mathrm{C}_{16: 1} \omega 7 c$ & 0 & $15 \cdot 87$ & 0 & 0 & 0 & $\mathrm{ND}$ \\
$\mathrm{C}_{16: 1} \omega 7 c / 15$ iso 2-OH & $0 \cdot 97$ & 0 & $8 \cdot 29$ & $2 \cdot 6$ & $6 \cdot 78$ & $\mathrm{ND}$ \\
$\mathrm{C}_{16: 0} 10-\mathrm{methyl}$ & 0 & 0 & $2 \cdot 78$ & $0 \cdot 8$ & $2 \cdot 84$ & $4 \cdot 0$ \\
$\mathrm{C}_{17: 1} \omega 8 c$ & $0 \cdot 53$ & $2 \cdot 79$ & $3 \cdot 60$ & $0 \cdot 9$ & $4 \cdot 54$ & $2 \cdot 9$ \\
$\mathrm{C}_{17: 0}$ & $1 \cdot 36$ & $1 \cdot 31$ & $3 \cdot 43$ & $2 \cdot 5$ & $3 \cdot 78$ & $3 \cdot 6$ \\
$\mathrm{C}_{18: 1} \omega 9 c$ & $47 \cdot 51$ & $16 \cdot 12$ & $29 \cdot 44$ & $30 \cdot 3$ & $19 \cdot 82$ & $13 \cdot 9$ \\
$\mathrm{C}_{18: 1} \omega 7 c$ & $0 \cdot 78$ & $2 \cdot 91$ & 0 & $0 \cdot 5$ & 0 & $2 \cdot 3$ \\
$\mathrm{C}_{18: 0}$ & $4 \cdot 24$ & $2 \cdot 20$ & $1 \cdot 87$ & $2 \cdot 9$ & $1 \cdot 44$ & $2 \cdot 7$ \\
$\mathrm{C}_{18: 3} \omega 6 c(6,9,12)$ & 0 & $1 \cdot 88$ & $\mathrm{ND}$ & $\mathrm{ND}$ & $\mathrm{ND}$ & $\mathrm{ND}$ \\
$\mathrm{C}_{19: 0}$ cyclo $\omega 10 c / 19 \omega 6$ & $4 \cdot 91$ & 0 & $\mathrm{ND}$ & $\mathrm{ND}$ & $\mathrm{ND}$ & $\mathrm{ND}$ \\
\hline
\end{tabular}

Type strain is KMM $3840^{\mathrm{T}}\left(=50-11^{\mathrm{T}}=\mathrm{DSM} 15401^{\mathrm{T}}\right)$. The DNA G + C content of the type strain is $59 \cdot 6 \mathrm{~mol} \%$. Isolated from a Bryozoa specimen collected in the Bering Sea.

\section{Description of Marinobacter sediminum sp. nov.}

Marinobacter sediminum (se.di.mi'num. L. gen. pl. n. sediminum of sediments, pertaining to source of isolation).

Gram-negative, aerobic, heterotrophic, oxidase- and catalase-positive, motile and rod-shaped $(1 \cdot 8-2 \cdot 5 \mu \mathrm{m}$ long and $0 \cdot 3-0 \cdot 4 \mu \mathrm{m}$ in diameter). Requires sodium ions for growth. Grows in $0 \cdot 5-18 \cdot 0 \%(\mathrm{w} / \mathrm{v}) \mathrm{NaCl}$ at $4-42{ }^{\circ} \mathrm{C}$. No growth is observed in $>18.5 \% \mathrm{NaCl}$ or at $>43^{\circ} \mathrm{C}$. Does not produce gelatinase, caseinase, amylase or chitinase. Does not produce acid from glucose, sucrose, lactose, maltose, galactose, arabinose, rhamnose, $N$-acetylglucosamine, glycerol or mannitol. API results are negative for $\beta$ galactosidase, indole production, arginine dihydrolase, urease production, aesculin, gelatin and utilization of L-arabinose, D-mannitol, maltose, D-mannose, $\mathrm{N}$-acetylglucosamine, D-gluconate, caprate, adipate, L-malate, citrate and phenylacetate. Biolog tests were positive for Tween 40, and weakly positive for Tween 80 hydrolysis and utilization of D-glucose, $\alpha$-ketobutyric acid and $\alpha$ ketovaleric acid; the other organic substrates included in the Biolog panel are not utilized. The whole-cell fatty acid composition is indicated in Table 2.

The type strain is $\mathrm{KMM} 3657^{\mathrm{T}}\left(=\mathrm{R} 65^{\mathrm{T}}=\mathrm{DSM} 15400^{\mathrm{T}}\right)$. The DNA G + C content of the type strain is $56.5 \mathrm{~mol} \%$.
Isolated from marine coastal sediments obtained from Peter the Great Bay, Sea of Japan, Russia.

\section{Acknowledgements}

This study was supported by grant no. 2-2.16 from the Ministry for Education and Science of the Russian Federation, and by grants from the Russian Academy of Sciences 'Molecular Cell Biology'. We thank Jolantha Swiderski for the phylogenetic analyses.

\section{References}

Allerberger, F. \& Fritschel, S. J. (1999). Use of automated ribotyping of Austrian Listeria monocytogenes isolates to support epidemiological typing. J Microbiol Methods 35, 237-244.

DeSoete, G. (1983). A least squares algorithm for fitting additive trees to proximity data. Psychometrika 48, 621-626.

Felsenstein, J. (1993). PHYLIP (phylogeny inference package), version 3.5.1. Department of Genetics, University of Washington, Seattle, USA.

Gauthier, M. J., Lafay, B., Christen, R., Fernandez, L., Acquaviva, M., Bonin, P. \& Bertrand, J.-C. (1992). Marinobacter hydrocarbonoclasticus gen. nov., sp. nov., a new, extremely halotolerant, hydrocarbondegrading marine bacterium. Int J Syst Bacteriol 42, 568-576.

Gorshkova, N. M., Ivanova, E. P., Sergeev, A. F., Zhukova, N. V., Alexeeva, Y., Wright, J. P., Nicolau, D. V., Mikhailov, V. V. \& Christen, R. (2003). Marinobacter excellens sp. nov., isolated from sediments of the Sea of Japan. Int J Syst Evol Microbiol 53, 2073-2078.

Jukes, T. H. \& Cantor, C. R. (1969). Evolution of protein molecules. In Mammalian Protein Metabolism, vol. 3, pp. 21-132. Edited by H. N. Munro. New York: Academic Press.

Leifson, E. (1963). Determination of carbohydrate metabolism of marine bacteria. J Bacteriol 85, 1183-1184.

Marmur, J. \& Doty, P. (1962). Determination of the base composition of deoxyribonucleic acid from its thermal denaturation temperature. J Mol Biol 4, 109-118.

Martín, S., Márquez, M. C., Sánchez-Porro, C., Mellodo, E., Arahal, D. R. \& Ventosa, A. (2003). Marinobacter lipolyticus sp. nov., a novel moderate halophile with lipolytic activity. Int J Syst Evol Microbiol 53, 1383-1387.

Nguyen, B. H., Denner, E. B. M., Dang, T. C. H., Wanner, G. \& Stan-Lotter, H. (1999). Marinobacter aquaeolei sp. nov., a halophilic bacterium isolated from a Vietnamese oil-producing well. Int J Syst Bacteriol 49, 367-375.

Owen, R. J., Hill, L. R. \& Lapage, S. P. (1969). Determination of DNA base composition from melting profiles in dilute buffers. Biopolymers 7, 503-516.

Rainey, F. A., Ward-Rainey, N., Kroppenstedt, R. M. \& Stackebrandt, E. (1996). The genus Nocardiopsis represents a phylogenetically coherent taxon and a distinct actinomycete lineage: proposal of Nocardiopsaceae fam. nov. Int J Syst Bacteriol 46, 1088-1092.

Shieh, W. Y., Jean, W. D., Lin, Y. T. \& Tseng, M. (2003). Marinobacter lutaoensis sp. nov., a thermotolerant marine bacterium isolated from a coastal hot spring in Lutao, Taiwan. Can J Microbiol 49, 244-252.

Smibert, R. M. \& Krieg, N. R. (1994). Phenotypic characterization. In Methods for General and Molecular Bacteriology, pp. 607-654. Edited by P. Gerhardt, R. G. E. Murray, W. A. Wood \& N. R. Krieg. Washington, DC: American Society for Microbiology.

Spröer, C., Lang, E., Hobeck, P., Burghardt, J., Stackebrandt, E. \& Tindall, B. J. (1998). Transfer of Pseudomonas nautica to Marinobacter hydrocarbonoclasticus. Int J Syst Bacteriol 48, 1445-1448. 
Stackebrandt, E. \& Goebel, B. M. (1994). Taxonomic note: a place for DNA-DNA reassociation and 16S rRNA sequence analysis in the present species definition in bacteriology. Int J Syst Bacteriol 44, 846-849.

Yoon, J.-H., Shin, D.-Y., Kim, I.-G., Kang, K. H. \& Park, Y.-H. (2003). Marinobacter litoralis sp. nov., a moderately halophilic bacterium isolated from sea water from the East Sea in Korea. Int J Syst Evol Microbiol 53, 563-568.

Yoon, J.-H., Yeo, S. H., Kim, I.-G. \& Oh, T. K. (2004). Marinobacter flavimaris sp. nov. and Marinobacter daepoensis sp. nov., slightly halophilic organisms isolated from sea water of the Yellow Sea in Korea. Int J Syst Evol Microbiol 54, 1799-1803. 